\title{
Struktur Komunitas Moluska di Perairan Pantai Grand Bali Beach Sanur, Bali
}

\author{
I Bagus Andreana Surya Nugraha ${ }^{\text {a*, }}$ Pande Gde Sasmita Julyantoro a, Suprabadevi \\ Ayumayasari Saraswati a \\ a Manajemen Sumberdaya Perairan, Fakultas Kelautan dan Perikanan, Universitas Udayana, Jimbaran, Badung, Bali-Indonesia \\ * Penulis koresponden. Tel.: +62-145-207-340 \\ Alamat e-mail: andreana.surya@yahoo.com
}

Diterima (received) 6 Juli 2018; disetujui (accepted) 9 Agustus 2018

\begin{abstract}
The purpose of this research was to investigate the community structure of mollusks, water quality and substrate type at Grand Bali Beach, Sanur. The research location was divided into 4 stations. This research was held in January until February 2018. The data was obtained from transect $1 \times 1 \mathrm{~m}$. The research was analysis by descriptive quantitative method. The research found about 33 species. The total abudance from station 1, 2, 3 and 4 were $5,75 \mathrm{ind} / \mathrm{m}^{2}, 6,0$ ind $/ \mathrm{m}^{2}, 6,0 \mathrm{ind} / \mathrm{m}^{2}$ and $9,0 \mathrm{ind} / \mathrm{m}^{2}$ respectively. The value of diversity was 2,0-2,52, indicated a moderate diversity while the evenness was $0,8-0,9$, that indicated the high evenness and the dominance was low about $0,11-0,19$. The community structure of mollusk at the Grand Bali Beach Sanur was still in normal condition for mollusk that supported by good water quality and favorable substrate type.
\end{abstract}

Keywords: Mollusks; Grand Bali Beach: Community structure.

\begin{abstract}
Abstrak
Penelitian ini bertujuan untuk mengetahui struktur komunitas moluska, kualitas air, dan tipe substrat yang berada di Perairan Pantai Grand Bali Beach Sanur. Lokasi penelitian dibagi menjadi 4 stasiun. Penelitian ini dilakukan pada bulan Januari-Februari 2018. Metode yang digunakan untuk pengambilan sampel adalah metode transek 1×1 m. Data yang diperoleh dianalisis secara deskriptif kuantitatif. Hasil penelitian mendapatkan spesies moluska sebanyak 33 jenis. Nilai kelimpahan total moluska dari stasiun 1, 2, 3 dan 4 masing-masing sebesar 5,75 ind $/ \mathrm{m}^{2}, 6,0$ ind $/ \mathrm{m}^{2}, 6,0$ ind $/ \mathrm{m}^{2}$ dan 9,0 ind $/ \mathrm{m}^{2}$. Nilai keaneakaragaman moluska di Pantai Grand Bali Beach berkisar antara 2,0-,2,52. Nilai tersebut tergolong dalam kategori keanekaragaman sedang. Nilai keseragaman moluska berkisar antara 0,8-0,9 yang tergolong keseragaman tinggi. Sedangkan nilai dominansi moluska berkisar antara 0,11-0,19. Nilai Struktur komunitas moluska di Pantai Sanur didukung oleh kualitas perairan yang masih bagus dan tipe substrat yang mendukung untuk kehidupan moluska.
\end{abstract}

Kata Kunci: Moluska; Pantai Grand Bali Beach; Struktur komunitas

\section{Pendahuluan}

Moluska merupakan organisme yang sangat penting bagi keseimbangan ekosistem di suatu perairan pantai. Organisme ini menyumbangkan zat kapur yang dapat menunjang pertumbuhan terumbu karang dan organisme ini juga memiliki peranan penting di dalam jaringan makanan (Romimohtarto dan Juwana, 2001). Rentang habitat moluska cukup luas, meliputi laut tropis sampai subtropis. Moluska dapat ditemui di daerah pinggiran pantai hingga laut dalam dengan kedalaman 0-700 $\mathrm{m}$, dan biasa juga ditemukan di daerah terumbu karang, membenamkan diri dalam sedimen, dan dapat juga menempel pada tumbuhan laut. Selain itu organisme ini dapat dijadikan sebagai bioindikator di suatu perairan dengan mengetahui struktur komunitas organisme tersebut di suatu perairan (Rachmawati, 2011). Moluska merupakan salah satu filum yang memiliki struktur komunitas spesies tinggi. Salah satu pantai di Bali yang memiliki struktur 
komunitas moluska adalah Pantai Grand Bali Beach Sanur.

Pantai Grand Bali Beach Sanur merupakan salah satu pantai yang berada di sebelah timur Kota Denpasar. Aktivitas sekitar di Pantai Grand Bali Beach Sanur tergolong padat, seperti tempat berlabuhnya kapal, tempat berekreasi, dan tempat berjualan. Pantai Grand Bali Beach Sanur memiliki jenis substrat berpasir yang berwarna putih dan menjadi tempat hidup berbagai spesies biota seperti lamun, bulu babi, berbagai jenis ikan dan moluska. Padatnya aktivitas manusia di suatu pantai seperti, sebagai tempat berlabuhnya kapal dan tempat berekreasi diperkirakan dapat mempengaruhi struktur komunitas moluska (Meisaroh, 2018).

Berdasarkan kondisi pantai tersebut, sangat penting dilakukan penelitian mengenai struktur komunitas moluska, kondisi kualitas air dan tipe substrat di Pantai Grand Bali Beach Sanur agar dapat mengetahui kondisi struktur komunitas moluska sehingga dapat diberikan pengelolaan yang sangat tepat dan dapat terjaganya kondisi perairan Pantai Grand Bali Beach Sanur.

\section{Metode Penelitian}

\subsection{Waktu dan Tempat}

Pengumpulan data dan pengamatan dilapangan dilakukan pada bulan Januari-Februari 2018 dan pengambilan data dilakukan ketika waktu surut terendah. Tempat pengambilan data lapangan bertempat di wilayah Pantai Sanur, tepatnya di zona litoral/intertidal Pantai Grand Bali Beach. Lokasi penelitian terbagi menjadi empat stasiun pengamatan. Selanjutnya pengamatan sampel yang diperoleh akan dilakukan di Laboratorium Perikanan Fakultas Kelautan dan Perikanan Universitas Udayana.

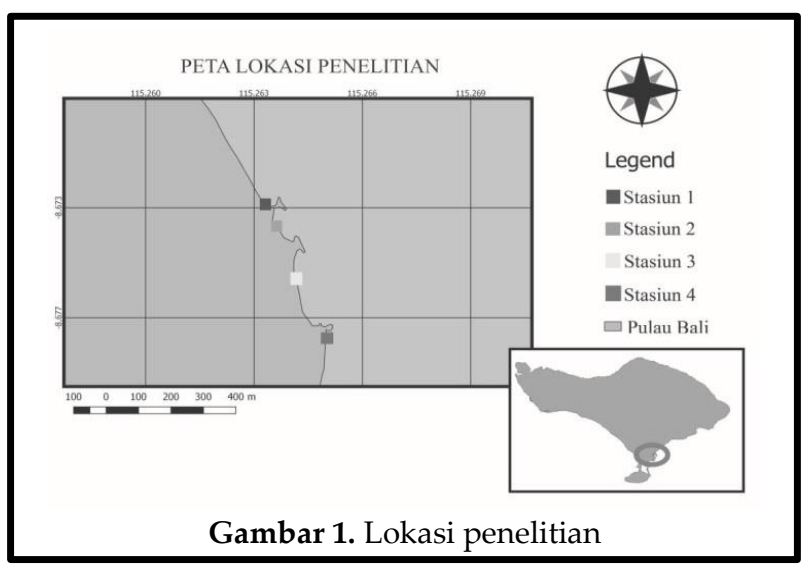

\subsection{Alat dan Bahan}

Alat dan bahan yang digunakan dalam penelitian yaitu transek kuadran $1 \times 1 \mathrm{~m}^{2}$, DO meter (PDO-519 Lutron), $\mathrm{pH}$ pen (PH-222 Lutron), refractometer (Master-PM Atago), buku identifikasi moluska, aquades dan alkohol $70 \%$.

\subsection{Metodologi}

\subsubsection{Metode penentuan titik sampling}

Penentuan titik sampling menggunakan metode purposive sampling. Metode purposive sampling merupakan metode penentuan titik sampling yang berdasarkan atas suatu pertimbangan tertentu seperti sifat-sifat populasi ataupun ciri-ciri yang sudah diketahui sebelumnya (Notoatmojo, 2010).

Lokasi penelitian terbagi menjadi empat stasiun pengamatan yaitu :

a. Stasiun 1 terletak di wilayah yang terdapat aliran air tawar dan terdapat pemberhentian kapal dengan titik koordinat $8^{\circ} 40^{\prime} 23.4^{\prime \prime} \mathrm{S}$ $115^{\circ} 15^{\prime} 47.4^{\prime \prime} \mathrm{E}$.

b. Stasiun 2 terletak di wilayah masyarakat melakukan aktivitas seperti berendam dan berenang dengan titik koordinat $8^{\circ} 40^{\prime} 24.2^{\prime \prime} \mathrm{S}$ $115^{\circ} 15^{\prime} 47.9^{\prime \prime} \mathrm{E}$.

c. Stasiun 3 terletak dilokasi pemberhentian kapal dan aktivitas manusia dengan titik koordinat $8^{\circ} 40^{\prime} 26.5^{\prime \prime} \mathrm{S} 115^{\circ} 15^{\prime} 48.9^{\prime \prime} \mathrm{E}$.

d. Stasiun 4 berlokasi pada tempat yang memiliki sedikit aktivitas manusia dan ditumbuhi lamun dengan titik koordinat $8^{\circ} 40^{\prime} 38.1^{\prime \prime} \mathrm{S} 115^{\circ} 15^{\prime} 53.9^{\prime \prime} \mathrm{E}$.

\subsubsection{Metode Penentuan Titik Sampling}

Pengambilan sampel dilakukan pada saat kondisi air surut. Setelah itu ditarik garis lurus sepanjang $75 \mathrm{~m}$ ke arah laut. Selanjutnya ditentukan titik-titik pengambilan sampel transek dengan pengambilan sampel masing-masing berjarak $25 \mathrm{~m}$. Setelah menentukan titik pengambilan sampel, transek kuadran diletakan di masing-masing titik dan diambil semua jenis moluska yang ada di dalam transek baik yang berada di atas substrat (epifauna) maupun yang berada didalam substrat (infauna) dengan kedalaman $20 \mathrm{~cm}$. Sampel moluska yang didapatkan, dimasukkan pada kantung plastik atau toples agar tidak terjadi kerusakan. Sampel moluska diawetkan dengan menggunakan alkohol 
$70 \%$ agar tidak terjadi kerusakan pada morfologi sampel. Seluruh sampel diamati dan diidentifikasi di laboratorium perikanan Fakultas Kelautan dan Perikanan Universitas Udayana dengan menggunakan buku Encyclopedia of Marine Gastropods (Robin, 2008).

\subsection{Analisis Data}

\subsubsection{Kelimpahan}

Kelimpahan dihitung dengan menggunakan rumus (Odum, 1971).

$$
K=\frac{n i}{A}
$$

dimana $\mathrm{K}$ adalah kelimpahan populasi (ind $/ \mathrm{m}^{2}$ ), ni adalah jumlah individu, $\mathrm{A}$ adalah luas area plot pengamatan $\left(\mathrm{m}^{2}\right)$.

\subsubsection{Keanekaragaman}

Rumus yang digunakan untuk menghitung Indeks keanekaragaman adalah rumus Shannon-Wiener (Krebs, 1989).

$$
\mathrm{H}^{\prime}=-\sum_{i=1}^{n} p i \ln p i
$$

dimana $\mathrm{H}^{\prime}$ adalah indeks keanekaragaman jenis, pi adalah ni/N, ni adalah jumlah individu ke-i, $\mathrm{N}$ adalah jumlah total individu.

\subsubsection{Keseragaman}

Rumus yang digunakan untuk menghitung indeks keseragaman adalah rumus (Krebs, 1989).

$$
E=\frac{H^{\prime}}{H m a k s}
$$

dimana $\mathrm{E}$ adalah indeks keseragaman, $\mathrm{H}^{\prime}$ adalah indeks keanekaragaman, $\mathrm{H}$ maks adalah Ln S.

\subsubsection{Dominansi}

Dominansi spesies tertentu dapat diketahui dengan menggunakan indeks dominansi Simpson (Magurran, 1987).

$$
C=\sum(p i)^{2}
$$

dimana $\mathrm{C}$ adalah indeks dominansi dan pi adalah ni/N.

\section{Hasil dan Pembahasan}

\subsection{Kekayaan spesies}

Spesies yang didapatkan dari keempat stasiun sebanyak 33 spesies. Spesies yang didapatkan dari keempat stasiun tersebut meliputi 1. Acteon tornatilis, 2. Amalda higendorfi, 3. Canarium wilsonorum, 4. Conus ebraeus, 5. Conus eburneus, 6. Conus janus, 7. Conus luquei, 8. Conus magelanicus, 9. Conus purpurascens, 10. Drupella margariticola, 11. Engina alveolata, 12. Engina turbinella, 13. Erosaria spurca, 14. Erosaria turdus, 15. Hastula rufonfuctata, 16. Littorina plena, 17. Mitra auriculoides, 18. Mitra paupercula, 19. Mitra retusa, 20. Mitrela austrina, 21. Mitrela ocelina, 22. Monetaria annulus-annulus, 23. Monetaria moneta, 24. Morula rumphiusi, 25. Nassarius callospina, 26. Nassarius myristicatus, 27. Nerita costata, 28. Nerita Insculpta, 29. Nerita saviena, 30. Olivia miniacea, 31. Patella vulgata, 32. Terebra Babylonia, 33. Vexillum alvinobalani. Gambar spesies yang ditemukan dapat dilihat pada Gambar 2.

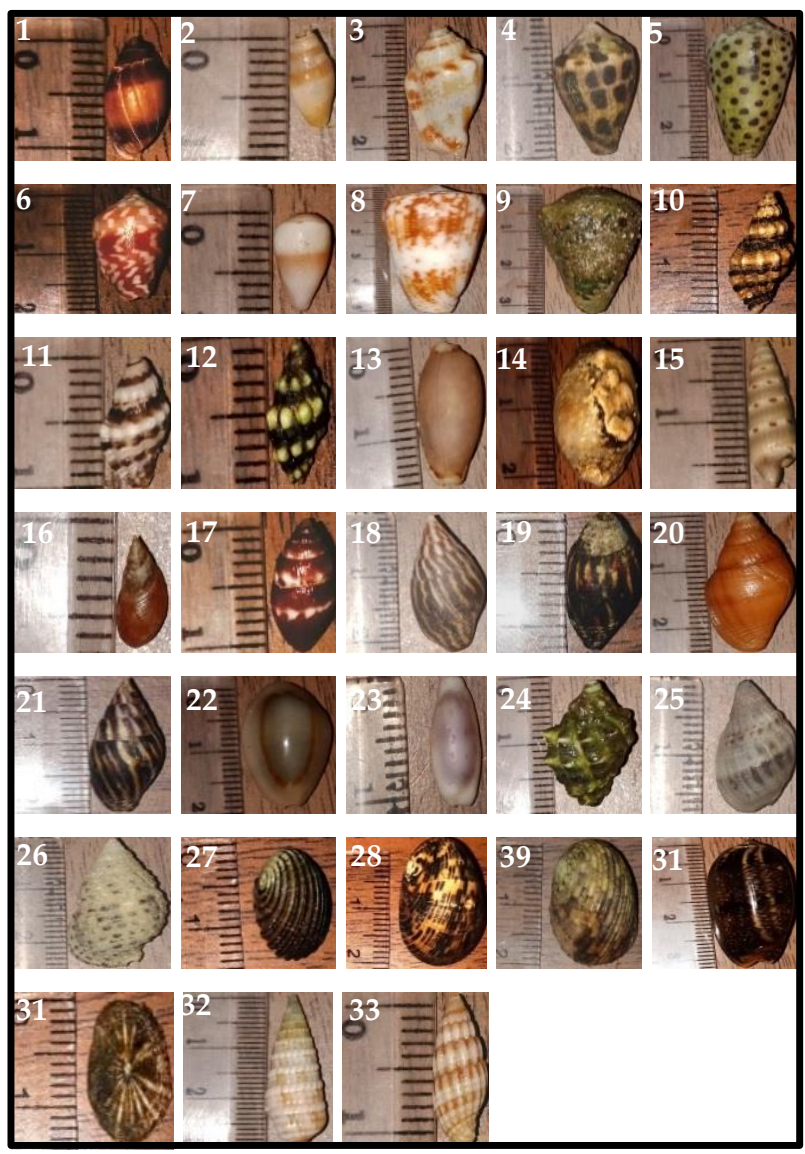

Gambar 2. Hasil identifikasi moluska pada stasiun 1, 2, 3, dan 4 di Pantai Grand Bali Beach

Spesies yang ditemukan hampir semuanya berbeda pada setiap stasiunya. Hanya saja 
terdapat beberapa spesies dapat ditemukan di seluruh stasiun di Pantai Grand Bali Beach seperti Engina turbinella, Mitra retusa, dan Morula rumphiusi. Spesies yang ditemukan pada masing-masing stasiun dapat dilihat pada tabel 1.

Spesies yang di temukan pada stasiun 1 berjumlah 12 spesies. Seluruh spesies yang ditemukan memiliki genus yang berbeda. Spesies yang ditemukan adalah Acteon tornatilis, Canarium wilsonorum, Drupella margariticola, Engina turbinella, Erosaria spurca, Littorina plena, Patella vulgata, Mitra retusa, Mitrela ocelina, Monetaria annulus-annulus,
Morula rumphiusi dan Nerita saviena.

Spesies yang ditemukan pada stasiun 2 berjumlah 11 spesies yang terdiri dari 9 genus yang berbeda. Spesies yang ditemukan adalah Amalda higendorfi, Conus eburneus, Conus luquei, Conus magelanicus, Engina turbinella, Mitra retusa, Mitrela austrina, Morulla rumphiusi, Nassarius myristicatus, Monetaria moneta, dan Nerita costata.

Spesies yang ditemukan pada stasiun 3 berjumlah 10 spesies yang terdiri dari 7 genus yang berbeda. Spesies yang ditemukan adalah Conus eburneus, Conus janus, Conus magellanicus,

Tabel 1

Spesies yang ditemukan pada masing-masing stasiun di Pantai Grand Bali Beach

\begin{tabular}{|c|c|c|c|c|c|}
\hline No & Nama Spesies & Stasiun 1 & Stasiun 2 & Stasiun 3 & Stasiun 4 \\
\hline 1 & Acteon tornatilis & + & - & - & - \\
\hline 2 & Amalda higendorfi & - & + & - & - \\
\hline 3 & Canarium wilsonorum & + & - & - & - \\
\hline 4 & Conus ebraeus & - & - & - & + \\
\hline 5 & Conus eburneus & - & + & + & + \\
\hline 6 & Conus janus & - & - & + & - \\
\hline 7 & Conus luquei & - & + & - & - \\
\hline 8 & Conus magelanicus & - & + & + & - \\
\hline 9 & Conus purpurascens & - & - & - & + \\
\hline 10 & Drupella margariticola & + & - & - & - \\
\hline 11 & Engina alveolata & - & - & + & + \\
\hline 12 & Engina turbinella & + & + & + & + \\
\hline 13 & Erosaria spurca & + & - & - & - \\
\hline 14 & Erosaria turdus & - & - & - & + \\
\hline 15 & Hastula rufonfuctata & - & - & - & + \\
\hline 16 & Littorina plena & + & - & - & - \\
\hline 17 & Mitra auriculoides & - & - & - & + \\
\hline 18 & Mitra paupercula & - & - & - & + \\
\hline 19 & Mitra retusa & + & + & + & + \\
\hline 20 & Mitrela austrina & - & + & - & - \\
\hline 21 & Mitrela ocelina & + & - & - & - \\
\hline 22 & Monetaria annulus-annulus & + & - & - & + \\
\hline 23 & Monetaria moneta & - & + & + & + \\
\hline 24 & Morula rumphiusi & + & + & + & + \\
\hline 25 & Nassarius callospina & - & - & - & + \\
\hline 26 & Nassarius myristicatus & - & + & - & + \\
\hline 27 & Nerita costata & - & + & - & - \\
\hline 28 & Nerita Insculpta & - & - & - & + \\
\hline 29 & Nerita saviena & + & - & - & - \\
\hline 30 & Olivia miniacea & - & - & + & - \\
\hline 31 & Patella vulgata & + & - & - & - \\
\hline 32 & Terebra Babylonia & - & - & + & - \\
\hline 33 & Vexillum alvinobalani & - & - & - & + \\
\hline \multicolumn{2}{|r|}{ Total Spesies } & 12 & 11 & 10 & 17 \\
\hline
\end{tabular}

Keterangan : (+) Ada, (-) Tidak ada 
Engina alveolata, Engina turbinella, Mitra retusa, Morula rumphiusi, Olivia miniacea, Monetaria moneta, dan Terebra babylonia.

Spesies yang ditemukan pada stasiun 4 berjumlah 17 spesies yang terdiri dari 10 genus yang berbeda. Spesies yang ditemukan adalah Conus eburneus, Conus purpurascens, Conus ebraeus, Engina alveolata, Engina turbinella, Erosaria turdus, Hastula rufonfuctata, Mitra auriculoides, Mitra paupercula, Mitra retusa, Monetaria annulus-annulus, Morulla rumphiusi, Nassarius callospina, Nassarius myristicatus, Nerita insculpta, Monetaria moneta, dan Vexillum alvinobalani.

\subsection{Struktur Komunitas}

Nilai kelimpahan jenis tertinggi terletak pada spesies Morulla rumphiusi dan Monetaria moneta yaitu sebesar 4,5 ind $/ \mathrm{m}^{2}$. Hal ini diduga diakibatkan oleh Pantai Grand Bali Beach Sanur memiliki habitat yang cukup baik untuk tempat tinggal dari kedua spesies tersebut. Famili dari cypraea biasanya hidup berkelompok dan hidup pada daerah pasang surut diantara batu karang dan banyak ditumbuhi algae (Oermajati dan wardana, 1990).

Nilai kelimpahan total moluska di Pantai Grand Bali Beach Sanur memiliki nilai 5,75 ind $/ \mathrm{m}^{2}$ hingga 9,0 ind $/ \mathrm{m}^{2}$. Grafik kelimpahan total moluska di Pantai Grand Bali Beach Sanur dapat dilihat pada Gambar 3.

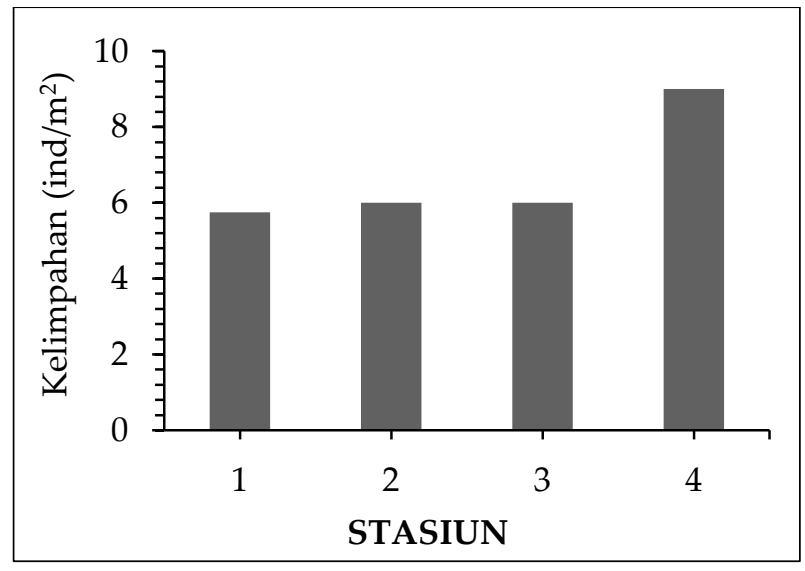

Gambar 3. Kelimpahan total moluska di Pantai Grand Bali Beach berkisar antara 5,75-9,0 ind $/ \mathrm{m}^{2}$.

Nilai kelimpahan total tertinggi terletak pada stasiun 4 yaitu sebesar 9,0 ind $/ \mathrm{m}^{2}$ Tingginya kelimpahan pada stasiun 4 diduga dipengaruhi oleh keadaan substrat di stasiun 4 yang sebagian besar substrat berpasir, bebatuan, pecahan karang dan terdapat lamun. Hitalessy (2015) menyatakan bahwa lamun merupakan habitat bagi makroozoobentos seperti moluska sebagai tempat untuk mencari makan dan sebagai tempat perlindungan dari predator. Selain itu, faktor lain yang mempengaruhi nilai kelimpahan pada stasiun 4 adalah sedikitnya aktifitas manusia di stasiun tersebut. Roy (2007) menyatakan bahwa banyaknya aktivitas manusia akan mempengaruhi struktur komunitas organisme seperti moluska. Kelimpahan total terendah terletak pada stasiun 1 yaitu sebesar 5,75 ind $/ \mathrm{m}^{2}$. Stasiun ini memiliki kelimpahan total yang lebih kecil daripada stasiun lainnya. Hal tersebut diduga oleh keadaan stasiun 1 yang terdapat sedikit ekosistem lamun. Frederiksen et al (2010) menyatakan bahwa organisme di daerah yang terdapat ekosistem lamun lebih banyak daripada daerah yang tidak memiliki ekosistem lamun.

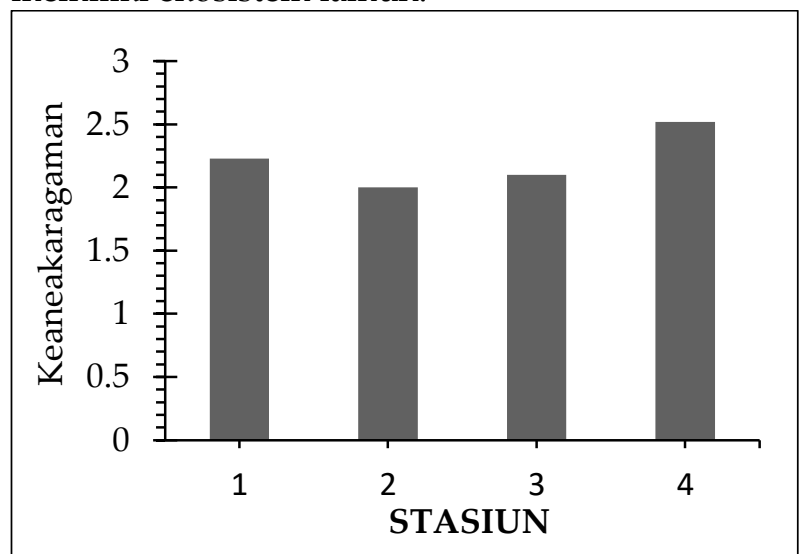

Gambar 4. Keanekaragaman moluska di Pantai Grand Bali Beach berkisar antara 2,0 - 2,52.

Stasiun 2 memiliki kelimpahan total sebesar 6,0 ind $/ \mathrm{m}^{2}$. Stasiun ini terletak di tempat banyaknya aktifitas manusia. Faktor yang diduga mempengaruhi kelimpahan moluska di stasiun 1 adalah adanya aktifitas manusia yang padat di stasiun tersebut. Meisaroh (2018) menyatakan bahwa aktivitas manusia seperti mengambil biota laut dapat mempengaruhi tinggi rendahnya kelimpahan makrozoobentos seperti moluska. Stasiun 3 memiliki kelimpahan total sebesar 6,0 ind $/ \mathrm{m}^{2}$. Stasiun ini terletak di lokasi tempat berlabuhnya kapal. Adanya kapal yang berlabuh diduga dapat mempengaruhi kelimpahan moluska. Brown dan McLachlan (2006) menyatakan bahwa lokasi berlabuhnya kapal dapat mempengaruhi keadaan ekosistem pantai berpasir. Sebaliknya Tan (2009) menyatakan lokasi pendaratan kapal tidak akan memberikan dampak yang signifikan terhadap kelimpahan moluska. 
Indeks keanekaragaman moluska di Pantai Grand Bali Beach Sanur menunjukan hasil keanekaragaman moluska yang berkisar antara 2,0-2,52. Hasil dari perhitungan indeks keanekaragaman dapat dilihat pada Gambar 4 . Indeks keaneakaragaman moluska di Pantai Grand Bali Beach Sanur memiliki nilai antara 2,0-2,52. Nilai keaneakaragaman tersebut masih tergolong sedang. Indeks keanekaragaman tertinggi terletak pada stasiun 4 yaitu sebesar 2,52. Tingginya keanekaragaman pada stasiun tersebut diakibatkan oleh sedikitnya aktivitas manusia, tipe substrat berpasir berbatu dan terdapat ekosistem lamun di stasiun tersebut. Fadli (2012) menyatakan bahwa substrat dasar yang berbatu merupakan lingkungan hidup yang baik bagi kehidupan makrozoobentos seperti moluska. Indeks keanekaragaman terendah terletak pada stasiun 2 yaitu sebesar 2,0. Rendahnya keanekaragaman pada stasiun 2 diakibatkan oleh banyaknya aktivitas manusia di stasiun tersebut dan hanya sedikit terdapat ekosistem lamun (Hitalessy, 2015).

Indeks keseragaman moluska di Pantai Grand Bali Beach Sanur menunjukan hasil keseragaman moluska yang berkisar antara 0,8 - 0,9. Hasil dari perhitungan indeks keseragaman dapat dilihat pada Gambar 5.

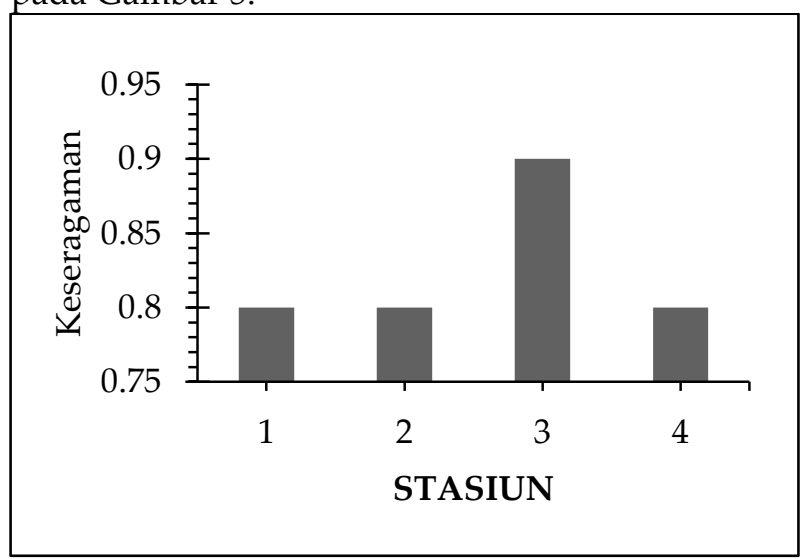

Gambar 5. Keseragaman moluska di Pantai Grand Bali Beach berkisar antara 0,8-0,9.

Indeks keseragaman di Pantai Grand Bali Beach Sanur menunjukan setiap stasiun memiliki keseragaman yang tinggi. Hal tersebut dilihat dari setiap stasiun memiliki nilai indeks keseragaman antara 0,8-0,9. Nilai tersebut menunjukan keseragaman lebih dari 0,6 yang berarti keseragaman yang tinggi (Brower, 1990). Keseragaman terendah terletak pada stasiun 1, stasiun 2 dan stasiun 4 yaitu sebesar 0,8. Keseragaman tertinggi terdapat pada stasiun 3 sebesar 0,9. Tingginya keseragaman di setiap stasiun di Pantai Grand Bali Beach Sanur di sebabkan oleh tidak adanya spesies yang mendominasi. Meisaroh (2018) menyatakan bahwa keseragaman yang tinggi menunjukan persebaran spesies merata dan tidak ada yang terlalu mendominasi.

Indeks dominansi moluska di Pantai Grand Bali Beach Sanur menunjukan hasil dominansi moluska yang berkisar antara $0,11-0,19$. Hasil dari perhitungan indeks dominansi dapat dilihat pada Gambar 6.

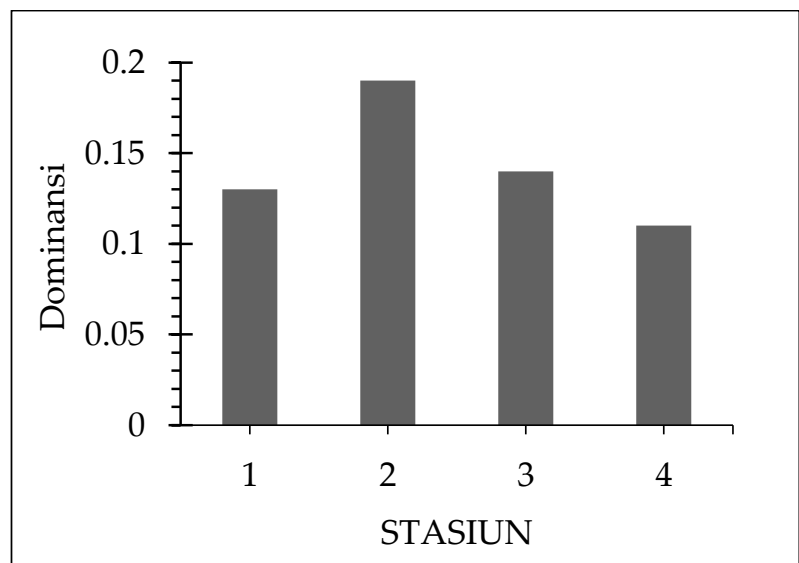

Gambar 6. Dominansi moluska di Pantai Grand Bali Beach berkisar antara 0,11-0,19.

Indeks Dominansi di Pantai Grand Bali Beach Sanur menunjukan setiap stasiun memiliki dominansi yang rendah. Hal tersebut dilihat dari setiap stasiun memiliki nilai indeks dominansi antara 0,11-0,19. Nilai tersebut menunjukan dominansi kurang dari 0,3 yang berarti dominansi rendah (Odum, 1993). Dominansi tertinggi terletak pada stasiun 2 yaitu sebesar 0,19 dan dominansi terendah terletak pada stasiun 4 yaitu sebesar 0,11 . Rendahnya dominansi di setiap stasiun tersebut diakibatkan oleh faktor kondisi perairan. Sukawati (2017) menyatakan bahwa lingkungan dan kondisi perairan tidak mendukung, maka hanya beberapa spesies saja yang memiliki kelimpahan yang tinggi dan mampu bertahan. Sehingga hal tersebut dapat menyebabkan dominansi yang tinggi.

\subsection{Kualitas Air}

Kualitas perairan pada setiap stasiun Pantai Grand Bali Beach Sanur masih tergolong baik yang mengacu pada baku mutu Peraturan Gubernur (Pergub) Bali Nomor 16 Tahun 2016 tentang biota laut dimana nilai DO (Dissolved oxygen) memiliki nilai lebih dari 5 , nilai salinitas memiliki nilai alami (kondisi normal suatu lingkungan), nilai $\mathrm{pH}$ 
sebesar 7,0-8,5 dan suhu memiliki nilai alami. Stasiun 4 yang memiliki kelimpahan tertinggi memiliki nilai DO sebesar $6,1 \mathrm{mg} / \mathrm{l}$ dan nilai tersebut merupakan nilai yang baik untuk kehidupan organisme akuatik. Effendi (2003) menyatakan bahwa nilai DO di perairan sebaiknya tidak kurang dari 5,0 mg/l karena hal tersebut akan menyebabkan efek yang kurang baik bagi seluruh organisme akuatik. Nilai salinitas pada stasiun 4 masih didalam kisaran optimal yaitu sebesar 30 ppt. Sinyo dan Idris (2013) menyatakan bahwa salinitas perairan yang mampu mendukung kehidupan di suatu perairan berkisar 27 ppt - 34 ppt. Nilai pH pada stasiun 4 masih didalam kisaran optimal yaitu 8,1. Pratiwi (2010) menyatakan nilai $\mathrm{pH}$ yang baik bagi kehidupan moluska berkisar 5,0-9,0. Nilai suhu dari stasiun 4 pada saat pengukuran masih didalam kisaran optimal yaitu sebesar $27,2^{\circ} \mathrm{C}$. Setiawan (2008) menyatakan bahwa suhu diatas $30^{\circ} \mathrm{C}$ dapat menekan kehidupan bentos seperti moluska.

Nilai kualitas perairan di stasiun 2 masih tergolong baik. Nilai DO pada stasiun 2 masih tergolong optimal yaitu sebesar 6,2 mg/l. Ridwan (2016) menyatakan bahwa batas minimum DO di perairan adalah 5,0 mg/l. Nilai salinitas pada stasiun 2 masih tergolong optimal yaitu sebesar 30 ppt. Ritniasih dan Widianingsih (2007) menyatakan bahwa moluska dapat hidup pada kisaran salinitas 5-35 ppt. Nilai $\mathrm{pH}$ pada stasiun 2 masih tergolong optimal yaitu sebesar 8 dan nilai suhu pada stasiun 2 masih tergolong optimal yaitu sebesar $27,3^{\circ} \mathrm{C}$. Nilai kualitas air pada stasiun 1 masih tergolong baik. Nilai DO pada stasiun 1 sebesar $6,3 \mathrm{mg} / \mathrm{l}$. Nilai salinitas pada stasiun 1 sebesar 27 ppt. Hal tersebut diakibatkan oleh adanya pengaruh air tawar yang bermuara di stasiun tersebut. Nilai $\mathrm{pH}$ pada stasiun 1 sebesar 8,2 . Nilai suhu pada stasiun 1 masih tergolong optimal yaitu sebesar $27^{\circ} \mathrm{C}$. Nilai kualitas perairan di stasiun 3 hampir sama dengan stasiun lainnya memiliki kualitas perairan yang optimal untuk mendukung kehidupan moluska. Nilai DO dari stasiun 3 masih tergolong optimal yaitu sebesar 6,2 $\mathrm{mg} / \mathrm{l}$. Nilai salinitas dari stasiun 3 masih tergolong optimal yaitu sebesar $30 \mathrm{ppt}$. Nilai $\mathrm{pH}$ dari stasiun 3 masih tergolong optimal yaitu sebesar 8,3. Dan nilai suhu dari stasiun 3 masih tergolong optimal untuk kehidupan moluska yaitu sebesar $27,3^{\circ} \mathrm{C}$ (Hasniar, 2013).

\subsection{Tipe Substrat}

Pantai Grand Bali Beach Sanur memiliki tipe substrat berpasir, berbatu dan berlumpur. Substrat berbatu merupakan lingkungan yang baik bagi kehidupan moluska. Substrat berbatu membantu memberikan perlindungan bagi moluska dari pergerakanarus (Fadli, 2012). Substrat berbatu merupakan habitat dari Morulla rumphiusi yang bertipe Rock snail. Keberadaan substrat berbatu tersebut dapat melindungi dari panas dan melindungi diri dari predator (Widiyansyah, 2016). Pantai Grand Bali Beach Sanur memiliki substrat berpasir. Substrat berpasir merupakan habitat yang baik untuk famili Cypraeidae. Parinsi (1997) menyatakan Cypraeidae umumnya ditemukan menempel pada batu atau karang mati dan membenamkan diri pada pasir. Pantai Grand Bali Beach Sanur juga memiliki campuran substrat pasir berlumpur. Substrat berpasir dan berlumpur memiliki kandungan bahan organik baik untuk kelangsungan hidup moluska (Sukawati, 2017). Campuran substrat berpasir dengan berlumpur merupakan substrat yang baik untuk kehidupan lamun. Hitalessy (2015) menyatakan bahwa lamun merupakan habitat yang baik bagi makroozoobentos seperti moluska sebagai tempat untuk berlindung dan mencari makan.

\section{Simpulan}

Kelimpahan total tertinggi terletak pada stasiun 4 yaitu sebesar 9,0 ind $/ \mathrm{m}^{2}$. Kelimpahan total terendah terletak pada stasiun 1 yaitu sebesar 5,75 ind $/ \mathrm{m}^{2}$. Kelimpahan total stasiun 2 dan 3 memiliki nilai yang sama yaitu sebesar 6,0 ind $/ \mathrm{m}^{2}$. Keanekaragaman pada stasiun 1 hingga stasiun 4 tergolong keanekaragmanan sedang. Keseragaman pada stasiun 1 hingga stasiun 4 tergolong keseragaman tinggi. Nilai Dominansi pada stasiun 1 hingga stasiun 4 tergolong dominansi rendah. Kualitas air pada stasiun 1 hingga stasiun 4 masih tergolong optimal untuk mendukung kehidupan moluska. Stasiun 1 hingga stasiun 4 memiliki tipe substrat yang sama yaitu berpasir dan berbatu. Tetapi stasiun 1 memiliki substrat berlumpur karena adanya air tawar yang bermuara di stasiun tersebut. Pantai Grand Bali Beach Sanur juga memiliki campuran substrat pasir berlumpur.

\section{Daftar Pustaka}

Brower, J., Jerrold, Z., \& Ende, C. V. (1990). Field and Laboratory Methods for Genera Zoology. (3rd ed). United States of America: W.M.C Brown Publishers. 
Effendi, H. (2003). Telaah Kualitas Air Bagi Pengelolaan Sumberdaya dan Lingkungan Perairan. Yogyakarta, Indonesia: Kanisius.

Fredriksen, S., A. D, Backer., C, Bostrom., H, Christie. (2010). Infauna from Zostera marina L. meadows in Norway. Differences in vegetated and unvegetated areas. Marine biology research, 6(2), 189-200.

Hasniar, H., M, Litaay., D, Priosambodo. (2013). Biodiversitas Gastropoda di Padang Lamun Perairan Mara Bombang Kabupaten Pinrang Sulawesi Selatan. Torani (Jurnal Ilmu. Kelautan dan Perikanan), 23(3), 127-136.

Hitalessy, R. B., Leksono, A. S., \& Herawati, E. Y. (2015). Struktur Komunitas Dan Asosiasi Gastropoda dengan Tumbuhan Lamun di Perairan Pesisir Lamongan Jawa Timur. J-PAL. 6(1). 64-73.

Mclachlan, A., \& Brown, A. C. (2006). The Ecology of Sandy Shore. USA: Elsevier Inc.

Meisaroh, Y. 2018. Struktur Komunitas Makrozoobenthos Sebagai Indikator Kualitas Perairan di Pantai Serangan Provinsi Bali. Bali. Journal of Marine and Aquatic Sciences, 5(1). 36-43.

Notoatmodjo, S. (2010). Metodologi Penelitian Kesehatan. Jakarta. Rineka Cipta

Odum, E. P. (1993). Dasar- Dasar Ekologi. Jakarta, Indonesia: Gramedia.

Oemarjati, B. S., \& Wardhana, W. (1990). Taksonomi Avertebrata. Jakarta. Penerbit Unversitas Indonesia.

Parinsi, A. (1997). Komunitas Gastropoda (Prosobranchia) di Daerah Rumput Laut Pantai Utara Minahasa. Manado. Skripsi. Manado, Indonesia: Fakultas Perikanan dan Ilmu Kelautan, Universitas Sam Ratulangi.

Peraturan Gubernur Bali. (2016). Baku Mutu Lingkungan Hidup dan Kriteria Baku Kerusakan Lingkungan Hidup. Bali, Indonesia: Pemerintah Propinsi Bali.

Pratiwi, R. (2010). Asosiasi Krustasea di ekosistem padang lamun perairan Teluk Lampung. Ilmu Kelautan: Indonesian Journal of Marine Sciences, 15(2), 66-76.

Rachmawaty, R. (2011). Indeks Keanekaragaman Makrozoobenthos Sebagai Bioindikator Tingkat
Pencemaran di Muara Sungai Jeneberang. Bionature, 12(2), 103-109.

Ridwan, M., Fathoni, R.., Fatihah, I., \&Pangestu, D. A. 2016. Struktur Komunitas makrozoobenthos di Empat Muara Sungai Cagar Alam Pulau Dua, Serang, Banten. Al-Kauniyah Jurnal Biologi, 9(1), 57-65.

Riniatsih, I., \& Widianingsih. (2007). Kelimpahan dan Pola Sebaran Kerang-kerangan (Bivalve) di Ekosistem Padang Lamun Perairan Jepara. Indonesian Journal of Marine Science, 12(1), 53-58.

Robin, A. 2008. Encyclopedia of marine gastropods. Germany: ConchBooks.

Romimohtarto, K., \& Juwana, S. (2001). Biologi Laut. Ilmu Pengetahuan Tentang Biota Laut. Jakarta, Indonesia: Djambatan.

Roy, K. 2007. Anthropogenic Impacts on Rocky Intertidal Mollusks in Southern California: Compiling Historical Baseline and Quantifying the Extent of the Problem. UC San Diego, California: Sea Grant College Program.

Setiawan, D. 2008. Struktur Komunitas Makrozoobentos Sebagai Bioindikator Kualitas Lingkungan Perairan Hilir Sungai Musi. Tesis. Bogor, Indonesia: Sekolah Pascasarjana, Institut Pertanian Bogor.

Sinyo, Y., \& Idris, J. (2013). Studi Kepadatan dan Keanekaragaman Jenis Organisme Bentos pada Daerah Padang Lamun di Perairan Pantai Kelurahan Kastela Kecamatan Pulau Ternate. Jurnal Bioedukasi, 2(1), 154-162.

Sukawati, A. (2017). Sebaran dan Struktur Komunitas Moluska di Pantai Mertasari Kota Denpasar, Provinsi Bali. Bali. Journal of Marine and Aquatic Sciences, 4(1). 78-85.

Tan, C. K. W. (2009). Effect of Trenching on Shell Size and Density of Turbo brunneus (Gastropoda: Turbinidae) and Monodonta labio (Gastropoda: Trochidae) at Labrador Beach, Singapore. Singapura: Nature In Singapore.

Widiansyah, A. T. (2016). Inventarisasi Jenis dan Potensi Mollusca di Zona Pasang Surut Tipe Substrat Berbatu Pantai Gatra Kabupaten Malang. Seminar Nasional Pendidikan dan Saintek, Program Studi Pendidikan Biologi, Universitas Negeri Malang. 